\title{
Energetics of food selection by the herbivorous parrotfish Sparisoma radians: roles of assimilation efficiency, gut evacuation rate, and algal secondary metabolites
}

\author{
Timothy E. Targett, Nancy M. Targett \\ University of Delaware, College of Marine Studies, Lewes, Delaware 19958, USA
}

\begin{abstract}
Experiments were conducted to investigate the effect of plant energy content and the presence of secondary metabolites on the assimilation efficiency, alimentary tract evacuation rate, and feeding rate of the bucktooth parrotfish Sparisoma radians. Alimentary tract evacuation rate was significantly greater (ca $2.5 \times$ ) when the fish fed on the relatively energy-poor calcareous green alga Halimeda incrassata than on the seagrass Thalassia testudinum. The greater evacuation rate of $H$. incrassata provided the fish the capacity to increase consumption rate to compensate for low food energy content. However, due to unpalatable secondary chemical metabolites present in $H$. incrassata, actual biomass consumed per unit time was less than for $T$ testudinum. Experiments using $T$ testudinum blades coated with $H$. incrassata organic crude extract showed that the secondary metabolites had no effect on the fish's assimilation efficiency or gut evacuation rate. The increased rate of $H$. incrassata evacuation is more than sufficient to allow compensation for lower gross energy content. $S$. radians can increase evacuation rate sufficiently to allow compensation for differences in available energy over the normal range for most plants consumed in nature. Studies of herbivorous fish foraging and feeding energetics must consider differences in alimentary tract evacuation rate and feeding rate, and the effects of secondary metabolites, in addition to the assimilation efficiency, structural defense and relative plant abundance factors usually considered.
\end{abstract}

\section{INTRODUCTION}

Studies of feeding selectivity in herbivorous fishes and the relative energy and nutrient value of their plant food have provided insight into factors involved in food choice by herbivorous fishes in tropical marine waters (Montgomery 1980, Montgomery \& Gerking 1980, Lobel 1981, Lobel \& Ogden 1981, Hay 1984) and in temperate seas (Edwards \& Horn 1982, Horn et al. 1982, 1985, Horn 1983, Horn \& Neighbors 1984). Diet choice should reflect selective feeding to maximize the rate of net energy gain (Pyke et al. 1977. Pyke 1979, Hughes 1980, Horn 1983). Energy value of the plant, assimilation efficiency of the fish for the plant, and nutrient content (in particular $\mathrm{N}$ or protein) are the factors generally considered when assessing food value relative to diet choice (Montgomery \& Gerking 1980,
Edwards \& Horn 1982, Horn et al. 1982, Horn 1983). In addition, secondary metabolites (Paul \& Hay 1986, Targett et al. 1986, Paul 1987, Wylie \& Paul 1988) and relative availability (Horn 1983, Horn \& Neighbors 1984) have been shown to influence food selection by herbivorous fishes. Thallus toughness may also restrict feeding by fishes with mouth structures incapable of effectively removing plant material (Littler et al. 1983, Paul \& Hay 1986).

The primary factors included in assessments of plant quality for herbivorous fishes have been those which influence assimilation per unit of plant material. Variation in consumption rate, made possible by differences in alimentary tract evacuation rate from one plant species to another, has not been previously considered. Since the rate of net energy gain is assumed to be the currency to be optimized, any factor causing changes 
in evacuation rate and consumption rate would affect the rate of energy gain.

Experiments with trout, marine flatfish, and other fishes fed artificial diets have shown increased evacuation rates when fed on diets low in energy (Rozin \& Mayer 1961, Grove et al. 1978, Flowerdew \& Grove 1979, Jobling 1980, 1981a, 1986, 1987, Jobling \& Wandsvik 1983). Since appetite is related to stomach or foregut fullness, feeding rate is strongly influenced by gastric or foregut emptying rate (Grove et al. 1978, Fange \& Grove 1979, Grove \& Crawford 1980, Holmgren et al. 1983, Knights 1985, Horn 1989). More rapid evacuation results in a more rapid increase in appetite. This provides fish with the capacity to increase feeding intensity and food intake rate when feeding on energypoor diets, and can result in maintenance of a relatively constant level of energy intake (Grove et al. 1978, Brett \& Groves 1979, Jobling 1980, 1983, Jobling \& Wandsvik 1983, Weatherley \& Gill 1987). The mechanisms by which gastric emptying rate is controlled and thereby linked to food intake have not been thoroughly examined, but it has been speculated that receptors in the anterior intestine respond to components in the chyme and in turn affect patterns of alimentary tract muscular contraction (see Jobling \& Wandsvik 1983, Jobling 1986, 1987).

Herbivorous fishes would therefore be expected to increase feeding rate on energy-poor plant material, and thus be able to maintain a relatively stable rate of energy intake across a range of plant quality. However, changes in evacuation rates and consumption rates with changes in plant energy content (and fish assimilation efficiency) have not been considered in fishes feeding on natural foods. Demonstration of such a relationship would alter the assessment of food value (rate of net energy gain) based primarily on energy or nutrient content and assimilation efficiency factors, and would also influence interpretation of patterns of food selection by herbivorous fishes.

Parrotfish (Scaridae) are common residents of tropical coral reefs and seagrass beds. The bucktooth parrotfish, Sparisoma radians, is an abundant herbivorous fish in Caribbean seagrass beds (Weinstein \& Heck 1979, Lobel \& Ogden 1981, Robblee \& Zieman 1984). This parrotfish is a browser which feeds on turtlegrass Thalassia testudinum, other seagrasses, and several macroalgal species including the calcareous green alga Halimeda incrassata (Lobel \& Ogden 1981). Previous laboratory and field studies have shown that $S$. radians feeds continuously, with nearly constant feeding intensity, during daylight (Lobel \& Ogden 1981). S. radians is typical of parrotfishes in that it has no true stomach, alkaline conditions ( $\mathrm{pH}$ ca 8.4) in the anterior intestine, and a pharyngeal mill with which food is finely ground (Lobel 1981).
Sparisoma radians feeds on plant types varying in energy content and digests them with a range of organic matter assimilation efficiencies (Lobel \& Ogden 1981). Laboratory and field studies (Lobel \& Ogden 1981, Targett et al. 1986) have established that $S$. radians prefers Thalassia testudinum, epiphytized and non-epiphytized, over algal species such as Halimeda incrassata. Lobel \& Ogden (1981) speculated that the large amount of structural $\mathrm{CaCO}_{3}$ in $\mathrm{H}$. incrassata lowered the energy content and biomass obtained per bite, thus decreasing preference by the fish. A role of $\mathrm{CaCO}_{3}$ in structural defense against herbivores has been suggested previously for Halimeda as well as other macroalgae (Paul \& Fenical 1983, Paul \& Hay 1986). However, Targett et al. (1986) demonstrated the importance of secondary metabolites produced by $H$. incrassata in influencing $S$. radians feeding preferences.

Sparisoma radians and its natural prey provide an opportunity to investigate the potential that evacuation rate and feeding rate may change with energy content of plant species and assimilation efficiency of the fish. Increased alimentary tract evacuation rate in $S$. radians when consuming energy-poor food such as Halimeda incrassata compared to Thalassia testudinum would demonstrate the capacity to compensate for low energy food by increasing consumption rate. In the absence of structural or chemical feeding deterrents the fish could increase feeding rate and at least partially compensate, in terms of energy assimilation rate, for low assimilation efficiency. Faster evacuation rate without a comparable increase in feeding rate could imply the role of feeding deterrents such as secondary metabolites. Secondary metabolites may simply be unpalatable, or it is possible that they also affect physiological processes such as assimilation efficiency or alimentary tract evacuation rate. Metabolites such as phenolic compounds have been speculated to inhibit digestive processes (Steinberg 1984, 1986, Horn et al. 1985, see also discussion in Lobel 1981), as have other compounds (Benitez \& Tiro 1982).

A series of experiments was conducted to investigate the relationship between plant energy content and the presence of secondary metabolites on Sparisoma radians assimilation efficiency, gut clearance rate, and feeding rate. The experiments were designed (1) to determine the energy content of Thalassia testudinum and Halimeda incrassata, and also the total, energy, and organic assimilation efficiency values for $S$. radians feeding on these plants; (2) to determine if evacuation rate is faster for energy-poor food such as $H$. incrassata than for $T$. testudinum, and if so, to determine if $S$. radians feeding rate increases comparably; and (3) to examine the effect of secondary metabolites in $H$. incrassata on assimilation efficiency and evacuation rate. 


\section{MATERIALS AND METHODS}

Specimen collection and preparation. Sparisoma radians were collected with a seine from seagrass beds along the east end of St. Croix, US Virgin Islands. They were held in flow-through aquaria and fed Thalassia testudinum prior to experiments. Three macrophyte food types were used in feeding experiments. The macroalga Halimeda incrassata and the seagrass $T$. testudinum (without epiphytes) were collected just prior to feeding the fish. The third food type was epiphyte-free $T$. testudinum blades coated with $H$. incrassata organic crude extract (ethyl acetate residue) at its naturally occurring concentration of ca $7.0 \mathrm{mg} \mathrm{g}^{-1}$ (see Targett et al. 1986). This food type was used to test the effects of $H$. incrassata secondary chemistry on digestive energetics. Extracts of $H$. incrassata were prepared from plants collected in the Florida Keys. Processing, extraction, and coating of the extract on Thalassia blades are described in Targett et al. (1986).

Feeding experiments. Two series of experiments were conducted. The first determined the energy content of the 3 food types and the assimilation efficiency for Sparisoma radians feeding on each. The second measured feeding rate and behavior of $S$. radians on each plant type separately and determined S. radians alimentary tract evacuation rate on each plant type.

Assimilation efficiency and food value: Prior to feeding, Sparisoma radians were held for ca $20 \mathrm{~h}$ in a flowthrough aquarium without food to clear their alimentary tracts. A group of $S$. radians was then fed one plant type by clipping freshly collected plants together with weighted wooden clips and placing them in the aquarium. The fish were allowed to feed for up to $4 \mathrm{~h}$ and were then all placed in a clean aquarium with nonflowing aerated seawater. Fecal pellets were siphoned from the bottom of the aquarium at $<1 \mathrm{~h}$ intervals for ca $6 \mathrm{~h}$. Excess water was removed from the accumulated fecal pellets by pipette and the material dried at $60^{\circ} \mathrm{C}$. A subsample of fresh plant material was weighed to the nearest $\mathrm{mg}$ wet weight, dried at $60^{\circ} \mathrm{C}$, reweighed, and the percentage water determined. Feeding was conducted on a different day for each food type with 4 to 9 fish per group. Water temperature throughout the experiments was $27^{\circ} \mathrm{C}$.

Dried macrophytes and fecal material were homogenized to a powder in a Wig L Bug homogenizer and energy content determined using a Phillipson microbomb calorimeter. The proportion of ash and organic matter in the macrophytes and fecal material was determined by heating at $450^{\circ} \mathrm{C}$ for $24 \mathrm{~h}$.

Assimilation efficiencies were calculated according to the method described by Montgomery \& Gerking (1980), which compares organic and ash contents of the food with the corresponding fecal material, using ash as a non-absorbed reference marker. The following equations were used:

Total Assimilation Efficiency $(\%)=$

$$
\left[1-\left(\frac{\% \text { ash in food }}{\% \text { ash } \text { in feces }}\right)\right] \times 100 \%
$$

'Nutrient' Assimilation Efficiency $(\%)=$

$$
\left[1-\left(\frac{\% \text { ash in food }}{\% \text { ash in feces }}\right) \times\left(\frac{\% \text { nutrient in feces }}{\% \text { nutrient in food }}\right)\right] \times 100 \%
$$

Assimilation efficiencies for energy and organic matter were calculated from Eq. (2) using $\mathrm{J} \mathrm{mg}^{-1}$ dry weight and percentage organic matter in the macrophytes and corresponding fecal material. This method assumes that ash is not significantly absorbed during the short experimental period. Any small absorption of minerals is considered negligible compared to the high percentage of ash in the plant material. Total assimilation efficiencies were also expressed in terms of wet weight after conversion using percentage water.

Feeding rate and alimentary tract evacuation rate: The feeding rate and feeding behavior of Sparisoma radians grazing on epiphyte-free Thalassia testudinum blades, Halimeda incrassata plants, and $T$. testudinum coated with $H$. incrassata organic crude extract was determined in a separate experiment for each food type. Fish were unfed for 18 to $20 \mathrm{~h}$ prior to each experiment. Experiments were conducted in a $75 \mathrm{l}$ flow-through aquarium at $26^{\circ} \mathrm{C}$. In each experiment a group of $4 \mathrm{~S}$. radians (52 to $70 \mathrm{~mm}$ total length) was allowed to feed for $4 \mathrm{~h}$ (ca 08:30 to 12:30 h). Separate measurements of feeding rate were acquired sequentially during this period, as the fish browsed continuously. Freshly collected plants were blotted dry, weighed, and clipped together with a weighted wooden clip. A clip of one plant type was placed on the bottom of the aquarium and the 4 fish were allowed to feed. Each hour the clip was replaced with a new clip of the same plant type. During the experiments, fish were observed continuously from behind black plastic blinds. Fecal material began to appear 1 to $2 \mathrm{~h}$ after feeding began and all feces produced during the $4 \mathrm{~h}$ was siphoned from the tank, dried at $60^{\circ} \mathrm{C}$, and weighed. The total number of bites taken during each $5 \mathrm{~min}$ interval of the $4 \mathrm{~h}$ feeding period was recorded and the percentage of bites subsequently rejected was estimated. At the end of the feeding period, macrophyte material remaining in each clip was blotted dry and weighed.

Each fish was then placed into an individual clean aquarium with non-flowing aerated seawater to determine alimentary tract evacuation rate. Fecal pellets were siphoned from each aquarium every $0.5 \mathrm{~h}$ for $6 \mathrm{~h}$ 
and again $12 \mathrm{~h}$ later. Preliminary results demonstrated that fecal production was complete by this time. Excess water was removed, and the feces from each time interval was dried separately at $60^{\circ} \mathrm{C}$ and weighed. This procedure was conducted on a different day for each food type.

Data analysis. Three methods were used to quantify feeding rates during the $4 \mathrm{~h}$ feeding period and to compare rates among foods. In the first method, the number of bites taken during each 5 min interval of the $4 \mathrm{~h}$ feeding period was compared among food types. The data for each food type were square-root transformed to achieve normality (determined by Kolmogorov-Smirnov tests using the Lilliefors option). Due to heteroscedasticity (determined using Bartlett's test) the transformed data were then analyzed using the Games and Howell method for making multiple comparison tests among pairs of means when variances are heterogeneous (Sokal \& Rohlf 1981). The other 2 methods assessed macrophyte biomass removed and consumed during the feeding period. Total wet weight of bites removed from plants during each $1 \mathrm{~h}$ interval was determined by subtracting the wet weight of plant material in each of the 4 clips after feeding from the initial wet weights. The data for each food type were normally distributed and homoscedastic. Data were analyzed by ANOVA and significant differences in wet biomass removed by the fish among food types determined using least significant difference (LSD) multiple comparison intervals. A significance level of $p<0.05$ was established a priori for these tests.

Because of difficulty determining precise wet weights for blotted plants, one other method was used for comparison. In this method, dry weight consumed was determined from dry weight of fecal material produced over the $22 \mathrm{~h}$ following initiation of feeding. The dry biomass of each macrophyte consumed was calculated according to the equation:

$$
W_{C}=\left(W_{F} \varnothing_{F}\right) / \varnothing_{C}
$$

where $W_{C}=$ dry weight in grams of food consumed during $4 \mathrm{~h} ; \mathrm{W}_{\mathrm{F}}=$ dry weight in grams of the feces produced; and $\varnothing_{\mathrm{F}}$ and $\varnothing_{\mathrm{C}}=$ the proportion of ash in feces and food, respectively (from Crisp 1984). This method assumes that ash is non-digestible and is not significantly absorbed during the short experimental period.

Alimentary tract evacuation rates were calculated separately for each of the 4 fish, for each food type. Fecal material recovered after each 30 min interval, for $6 \mathrm{~h}$ after transfer to food-free aquaria, was weighed and these values summed with the weight recovered $12 \mathrm{~h}$ later. All weights were then converted to a percentage of the total recovered from each fish. Percentage food remaining $(\mathrm{y})$ vs time $(\mathrm{x})$ over the $6 \mathrm{~h}$ period was a curvilinear function in all cases and 2 volumedependent emptying models were applied (Jobling 1981b, 1986, 1987). Transforming the percentage values by either square root or natural logarithm both provided good linear fits to the data. The negative exponential (natural logarithm) model $\left(y=\mathrm{ae}^{-\mathrm{bx}}\right.$ ) was chosen because it has been shown to best describe the emptying curve for fishes feeding on relatively low energy diets and ingesting small particles (Jobling 1986, 1987) and for other species of stomachless fishes (Grove \& Crawford 1980, Persson 1982, Beyer et al. 1988). Thus, alimentary tract evacuation rate was calculated for each fish from the linear regression equation:

$$
\ln \mathrm{W}_{\mathrm{T}}=\ln \mathrm{W}_{0}-\mathrm{bT}
$$

where $\mathrm{W}_{\mathrm{T}}=$ percentage food remaining in the gut +1 at time $\mathrm{T}$ after feeding ceased; $\mathrm{W}_{0}=$ the $\mathrm{y}$ intercept $-b=$ the instantaneous rate of evacuation (slope); and $T=$ time ( $\mathrm{h}$ ) (see Jobling 1981b). Adding 1 to the percentage food remaining values allowed inclusion of 0 values (empty alimentary tracts at the end of the $6 \mathrm{~h}$ period). The exponential model assumes that a constant proportion of the food material is evacuated per unit time and thus the time necessary for complete evacuation does not depend upon meal size (Jobling $1981 b)$. Subsequent regression analysis of the predicted times for complete evacuation ( $\mathrm{T}$ when $\ln \mathrm{W}_{\mathrm{T}}=$ 0 , for each fish for a particular food type) vs the amount of feces produced in the food-free aquarium (meal size) showed no relationship, providing additional support for use of the exponential model for the determination of evacuation rate. Evacuation rate data for each food type were normally distributed and homoscedastic and rates were compared among food types with ANOVA and LSD multiple comparison intervals $(p<0.05)$.

\section{RESULTS}

The organic content and energy content of Thalassia testudinum were much higher than for Halimeda incrassata (Table 1). The differences in food quality were reflected in much higher assimilation efficiency values for Sparisoma radians feeding on $T$. testudinum than on $H$. incrassata in terms of percentage total weight, organic matter, and energy (Table 1). The high ash content (primarily structural $\mathrm{CaCO}_{3}$ ) in $\mathrm{H}$. incrassata greatly reduced the organic and energy content, and total dry weight assimilation efficiency was only $3 \%$.

The alimentary tract evacuation rate of Sparisoma radians was significantly greater for Halimeda incrassata than for Thalassia testudinum (Table 2). Mean instantaneous evacuation rate (slope of $\log _{e}$-transformed data) was -0.5382 for $H$. incrassata compared 
Table 1. Organic and energy content of macrophytes with associated assimilation efficiency by Sparisoma radians

\begin{tabular}{|c|c|c|c|c|c|c|c|c|c|}
\hline \multirow[t]{3}{*}{ Macrophyte } & \multirow[t]{3}{*}{$\%$ Water } & \multicolumn{2}{|c|}{ Organic matter } & \multirow{2}{*}{\multicolumn{2}{|c|}{$\begin{array}{c}\text { Energy content } \\
\left(\mathrm{J} \mathrm{mg}^{-1}\right)\end{array}$}} & \multicolumn{4}{|c|}{ Assimilation efficiency $(\%)$} \\
\hline & & \multirow{2}{*}{$\begin{array}{c}\% \\
\text { wet wt }\end{array}$} & \multirow{2}{*}{$\begin{array}{c}\% \\
\text { dry wt }\end{array}$} & & & \multicolumn{2}{|c|}{ Total } & \multirow[t]{2}{*}{ Organic } & \multirow[t]{2}{*}{ Energy } \\
\hline & & & & Wet wt & Dry wt & Wet & Dry & & \\
\hline Thalassia testudinum & 83 & 12 & 71 & 2.2 & 12.7 & 7 & 39 & 56 & 64 \\
\hline Halimeda incrassata & 76 & 5 & 19 & 1.2 & 4.9 & 1 & 3 & 19 & 10 \\
\hline \multicolumn{10}{|l|}{ T. testudinum coated with } \\
\hline Halimeda organic extract & 77 & 18 & 77 & 3.5 & 15.2 & 10 & 46 & 59 & $-{ }^{a}$ \\
\hline
\end{tabular}

Table 2. Sparisoma radians. Mean instantaneous evacuation rates, y intercepts, and times for complete evacuation ( \pm SE) of macrophytes from the alimentary tract

\begin{tabular}{|c|c|c|c|}
\hline Macrophyte & $\begin{array}{c}\text { Instantaneous evacuation } \\
\text { rate }^{\text {a }}\end{array}$ & $y$-intercept ${ }^{a}$ & $\begin{array}{l}\text { Time for complete } \\
\text { evacuation (h) }\end{array}$ \\
\hline Thalassia testudinum & $-0.2166 \pm 0.0307^{b}$ & $96.35 \pm 4.12^{b}$ & $22.4 \pm 3.2^{b}$ \\
\hline Halimeda incrassata & $-0.5382 \pm 0.1286^{c}$ & $134.63 \pm 19.02^{b}$ & $11.5 \pm 3.7^{\mathrm{c}}$ \\
\hline \multicolumn{4}{|l|}{ T. testudinum coated with } \\
\hline Halimeda organic extract & $-0.2730 \pm 0.0460^{\mathrm{b}}$ & $111.48 \pm 8.68^{b}$ & $18.3 \pm 2.2^{\mathrm{b}, \mathrm{c}}$ \\
\hline \multicolumn{4}{|c|}{$\begin{array}{l}\text { a Instantaneous evacuation rate is the mean slope }(-\mathrm{b}) \text {, and } \mathrm{y} \text { intercept is the mean value of } \mathrm{W}_{0} \text {, from the equation } \mathrm{ln} \mathrm{W}_{\mathrm{T}}=\mathrm{ln} \\
\mathrm{W}_{0}-\mathrm{bT} \text {, over all } 4 \text { fish. } \mathrm{W}_{\mathrm{T}} \text { is percentage food remaining in the gut }+1 \text { at time } \mathrm{T} \text { after feeding ceased and } \mathrm{T} \text { is time }(\mathrm{h}) \\
\mathrm{b}, \mathrm{c} \text { Means having the same superscript within a column are not significantly different by ANOVA at } \mathrm{p}<0.05\end{array}$} \\
\hline
\end{tabular}

with -0.2166 for $T$. testudinum. Thus, evacuation rate for energetically poorer $H$. incrassata was ca $2.5 \times$ greater than for $T$. testudinum, providing $S$. radians the capacity to increase consumption rate to allow compensation for low plant energy content.

Feeding rate was quantified in 3 ways (Table 3 ). Although the higher number of bites taken by Sparisoma radians per unit time from Halimeda incrassata was not statistically different than the number taken from Thalassia testudinum (Table 3), ca $40 \%$ of the bites taken from $H$. incrassata were rejected immediately, compared with $<1 \%$ from $T$. testudinum. This lowered the actual consumption rate of bites from
$H$. incrassata to a level significantly lower than from $T$. testudinum (Table 3). Although $15 \%$ more bites were taken, ca $31 \%$ fewer bites of $H$. incrassata were actually consumed, relative to $T$. testudinum plants.

The 2 other methods of assessing feeding rate were more quantitative and showed analogous results. Wet weight of macrophyte removed during $1 \mathrm{~h}$ intervals over the $4 \mathrm{~h}$ feeding experiment did not differ statistically between Thalassia testudinum and Halimeda incrassata, but when adjusted for percentage $H$. incrassata bites rejected, actual consumption of $H$. incrassata was significantly less (28\% lower) than for $T$. testudinum (Table 3). Dry weight of macrophyte con-

Table 3. Sparisoma radians. Feeding rates of fish on macrophytes during 4 h tests when given no plant choice

\begin{tabular}{|c|c|c|c|c|c|c|}
\hline \multirow[t]{2}{*}{ Macrophyte } & \multicolumn{2}{|c|}{$\begin{array}{l}\text { Mean number of bites } \\
\text { removed (A) and consumed (B) } \\
5 \mathrm{~min}^{-1}\end{array}$} & \multicolumn{2}{|c|}{$\begin{array}{l}\text { Mean biomass of bites } \\
\text { removed (A) and consumed } \\
\text { (B) } h^{-1} \text { (g wet wt) }\end{array}$} & \multirow{2}{*}{$\begin{array}{l}\text { Biomass of } \\
\text { macrophyte } \\
\text { consumed in } \\
4 \mathrm{~h} \text { (g dry wt) }\end{array}$} & \multirow[t]{2}{*}{$\begin{array}{l}\text { Percentage } \\
\text { rejections }^{\mathrm{b}}\end{array}$} \\
\hline & A & $\mathrm{B}^{\mathrm{a}}$ & A & $\mathrm{B}^{\mathrm{a}}$ & & \\
\hline Thalassia testudinum & $36.42^{c}$ & $36.42^{c}$ & $0.2426^{c}$ & $0.2426^{\mathrm{c}}$ & 0.3827 & $<1$ \\
\hline Halimeda incrassata & $41.96^{c, d}$ & $25.12^{\mathrm{d}}$ & $0.2924^{c}$ & $0.1754^{\mathrm{d}}$ & 0.2390 & 40 \\
\hline \multicolumn{7}{|l|}{$T$ testudinum coated with } \\
\hline Halimeda organic extract & $28.71^{\mathrm{d}}$ & $28.71^{\mathrm{d}}$ & $0.1508^{d}$ & $0.1508^{\mathrm{d}}$ & 0.2476 & $<5$ \\
\hline \multicolumn{7}{|c|}{ a Adjusted for percentage $H$. incrassata bites rejected } \\
\hline \multicolumn{7}{|c|}{ b Observational estimate } \\
\hline
\end{tabular}


sumed, based on dry weight of fecal material produced (adjusted for assimilation efficiency), was also less (38\% lower) for $H$. incrassata than for $T$. testudinum.

Although the greater evacuation rate provides Sparisoma radians with the capacity to increase feeding rate on energy-poor Halimeda incrassata, actual biomass consumed was less than from Thalassia testudinum due to rejections. When feeding on $H$. incrassata, $S$. radians was observed to take most bites from the highly calcified bases of the plants. Nearly all of the bites taken from $H$. incrassata plant tips were rejected.

Experiments using Thalassia testudinum blades coated with Halimeda incrassata organic crude extract provided insight into the potential influence of unpalatable secondary metabolites on Sparisoma radians assimilation efficiency, alimentary tract evacuation rate, and feeding rate and behavior. Coating the organic extract on $T$. testudinum blades removed water and added organic matter and energy, compared with uncoated blades (Table 1). Assimilation efficiency was not decreased, and in fact was slightly higher for blades coated with extract on both wet and dry weight bases. Alimentary tract evacuation rate of coated blades was not significantly different from uncoated blades (Table 2). Feeding rate, however, was significantly altered by presence of the organic crude extract. Fewer bites were taken and consumed from coated blades than from uncoated blades (Table 3). Rejection rate was estimated to be $<5 \%$ compared with $<1 \%$ for uncoated blades. However, the number of bites taken and consumed from coated blades was not significantly different than the number taken from $H$. incrassata plants. Wet biomass of macrophyte removed and consumed was also significantly less for coated than for uncoated $T$. testudinum blades. Dry weight analysis also showed $35 \%$ less consumption of coated than uncoated blades.

Compared with Halimeda incrassata plants, less biomass was removed from coated Thalassia testudinum blades; but due to high rejection rates for $H$. incrassata, biomass actually consumed was the same in both the wet and dry weight analyses (Table 3). Coating T. testudinum blades with $H$. incrassata organic crude extract at naturally occurring concentrations reduced actual consumption rate to a level not significantly different than that on whole $H$. incrassata plants.

\section{DISCUSSION}

Sparisoma radians has a significantly faster (ca $2.5 \times$ ) instantaneous rate of alimentary tract evacuation when feeding on Halimeda incrassata than when consuming Thalassia testudinum. Since more rapid evacuation leads to a more rapid increase in appetite in fishes
(Grove et al. 1978, Fange \& Grove 1979, Grove \& Crawford 1980, Holmgren et al. 1983, Knights 1985 , Horn 1989), S. radians has the capacity to increase consumption rate to compensate for low food energy and low assimilation efficiency. However, consumption of $H$. incrassata plants does not increase, and in fact feeding rate is reduced relative to the rate on $T$. testudinum blades. Furthermore, although $H$. incrassata organic crude extract reduces consumption of $T$. testudinum blades, the compounds do not alter $S$. radians digestive efficiency or rate. The secondary metabolites, which include 1,4-diacetoxy-1,3-butadiene terpenes, are unpalatable and alter feeding rate and food preference (Targett et al. 1986) but do not appear to affect $S$. radians digestive energetics.

The conclusion has often been made that calcareous algae, or other plants of low energy value, are or should be avoided as food by herbivorous fishes because of reduction in rate of net energy gain by the fish (Montgomery \& Gerking 1980, Lobel \& Ogden 1981, Horn et al. 1982). The relationship between energy content and rate of evacuation by Sparisoma radians demonstrates that increased evacuation rate, and thus the capacity to increase feeding rate on energy-poor food, must be considered in assessments of relative plant value and food preferences in herbivorous fishes. As long as chemical or structural defense mechanisms in the plant do not limit the fishes feeding rate and ability to maintain a full gut, then compensation for low energy level food is possible. Low energy content would, therefore, be a significant factor affecting the net rate of energy intake only (1) when low enough to more than offset the capacity of increased evacuation rate to sufficiently increase intake rate, or (2) if the time necessary to forage for the increased food intake placed constraints on the fish.

Gastric evacuation and food consumption rates in fishes are generally found to change in proportion to digestible (net) food energy rather than total (gross) energy content (see Jobling 1983, Jobling \& Wandsvik 1983), although some data have suggested a better relationship to total energy (see Jobling 1981a). The increased rate of evacuation of Halimeda incrassata compared with Thalassia testudinum by Sparisoma radians is more than sufficient to allow compensation for lower gross energy content of $H$. incrassata on a wet weight basis, but not sufficient to fully compensate for the lower energy assimilation efficiency found (net energy content). Restraints imposed by alimentary tract muscular contraction rates may limit evacuation rates and cause increases to be inadequate to maintain a constant rate of energy intake for fishes feeding on food of very low energy value (Jobling 1980). Such a limitation on intake rate was speculated to be the cause of the inability of rainbow trout Salmo gairdnen to 
increase evacuation and food intake rate to compensate for more than $30 \%$ cellulose filler added to fish meal artificial diets (Bromley \& Adkins 1984). On the other hand, if the low energy assimilation efficiency $(10 \%)$ found in the present study for $H$. incrassata is actually higher (Lobel \& Ogden [1981] reported $81 \%$ assimilation efficiency for dry organic matter), then the increased evacuation rate demonstrated could also compensate for lower net (digestible) energy content.

The relative roles of structural and chemical defense mechanisms in marine macroalgae as deterrents to herbivory by fishes has been examined by Paul \& Hay (1986). They concluded that morphological defenses alone do not appear to be adequate to defend most algal species and noted the general occurrence of biologically active secondary metabolites in calcareous algae. Herbivorous parrotfish, such as Sparisoma radians, are well adapted for the consumption of heavily calcified prey. The specialized teeth, strong jaws, and pharyngeal mill typical of parrotfishes enable other species in this group to ingest hard corals (Hiatt \& Strasburg 1960, Randall 1967). Therefore, whereas thallus calcification may function to reduce herbivory by fishes such as damselfishes and angelfishes (see discussion by Hay 1984) which have small, weak mouths, algal thallus calcification is unlikely to be a physical deterrent to herbivory by fishes such as parrotfishes. In addition, the reduction in algal energy content which accompanies calcification does not function as a deterrent to the rate of net energy intake either, if evacuation rates and consumption rates increase and compensate for low energy content. These factors are consistent with the commonly observed occurrence of multiple defenses in calcified macroalgae (see Paul \& Hay 1986).

Sparisoma radians has been demonstrated to increase evacuation rate sufficiently to allow compensation for differences in available energy over the normal range for most plants consumed in nature (see values in Lobel \& Ogden 1981). We speculate that the increased evacuation rate would result in greater removal and consumption rate of Halimeda incrassata if it were not for the presence of secondary metabolite feeding deterrents (see Targett et al. 1986). In the natural environment, the fish's demonstrated avoidance of $H$. incrassata would manifest itself in the choice of other plant species (Lobel \& Ogden 1981, Targett et al. 1986). Furthermore, although S. radians appears to not have the capacity to fully compensate for low energy assimilation efficiency (net energy content), Halimeda could still be consumed without energetic detriment as part of a mixed diet including other more energy rich macrophytes. The secondary metabolite feeding deterrents in Halimeda may serve as a second line of defense against herbivores such as parrotfishes, which have strong jaws and pharyngeal mills. The mixed diets often consumed by herbivorous fishes (see Horn et al. 1982, Horn 1983) may provide a better balance of nutrients than a single plant diet, and greater alimentary tract evacuation rate with an associated increase in feeding rate may allow compensation for the energy dilution associated with inclusion of lower energy value plants.

Sparisoma radians feeding on Thalassia testudinum in the present study had an assimilation efficiency of $56 \%$ of dry organic matter. This is greater than the value of only $7 \%$ reported by Lobel \& Ogden (1981). However, $7 \%$ is lower than would be expected based on organic and energy content despite the occurrence of indigestible cellulose (see Thayer et al. 1984). Organic assimilation efficiency of herbivorous sea urchins feeding on $T$. testudinum has been reported to range from $19 \%$ in Lytechinus variegatus (Lowe \& Lawrence 1976) to $37 \%$ in Echinometra lucunter (Lawrence 1976). Greenway (1976) reported $65 \%$ assimilation efficiency for total dry weight in $L$. variegatus feeding on $T$. testudinum. Furthermore, the southern Australian halfbeak Hyporhamphus melanochir like S. radians has a pharyngeal mill, no true stomach, and a near-neutral gut $\mathrm{pH}(6.5$ to 7.0$)$. This fish has an organic matter assimilation efficiency of $38 \%$ feeding on the seagrass Heterozostera tasmanica (Klumpp \& Nichols 1983). These data, therefore, agree with the higher assimilation efficiency found in the present study for $S$. radians feeding on $T$. testudinum.

In their calculations of plant energy value, Lobel \& Ogden (1981) multiplied dry organic matter assimilation efficiency by caloric content and 'biteability' (the plant biomass obtained per bite). They concluded from these calculations that Halimeda incrassata had the lowest net food value of the plants tested, including Thalassia testudinum and that this was the basis for the demonstrated avoidance of $H$. incrassata by Sparisoma radians. However, the 'biteability' term was an order of magnitude lower for $H$. incrassata than for $T$. testudinum and accounts for the majority of the difference in calculated food value. S. radians was shown in the present study to remove similar biomass per unit time when feeding on these 2 plants, and thus is not deterred from filling its gut by plant structural toughness. The 'biteability' term, therefore, should have little influence on actual net energy value. Based on the present results and those reported by Targett et al. (1986), the avoidance of $H$. incrassata appears to be due largely to the presence of secondary metabolites.

In summary, Sparisoma radians feeding on natural prey does, as predicted, increase alimentary tract evacuation rate when feeding on energy-poor plants, and has the potential to increase feeding rate to compensate for low food value. Differences in assimilation 
rate can therefore overlie assimilation efficiency considerations, and the rate of net energy gain cannot be determined simply by multiplying plant energy content by assimilation efficiency and calculating net energy content. Furthermore, high plant ash content may be a feeding deterrent for $S$. radians only because assimilation efficiency of energy (net plant energy content) is apparently so low. The avoidance of Halimeda incrassata by $S$. radians is due largely to unpalatable Halimeda secondary chemistry. Studies of herbivorous fishes' feeding energetics and plant choice must consider differences in alimentary tract evacuation rate and feeding rate, and the effects of secondary metabolites, as well as the assimilation efficiency, structural defense, and relative plant abundance factors usually considered.

Acknowledgements. We thank J. Ogden for facilitating this work by providing laboratory space at the West Indies Laboratory and for helpful discussions on the topic of herbivory; R. Carpenter and N. Ogden for their insight on algal distribution and ecology and discussions on plant/herbivore interactions; N. Vrolijk, J. Galluzzo, and D. Frey for laboratory and field assistance. Thanks also go to K. Young for work on the microbomb calorimetry. We thank P. Gaffney and D. Miller for discussions on data treatment and statistical analyses, and 3 anonymous reviewers for helpful comments on the manuscript. This paper is Contribution no. 198 of the West Indies Laboratory, Fairleigh Dickinson University, St. Croix, US Virgin Islands.

\section{LITERATURE CITED}

Benitez, L. V., Tiro, L. B. (1982). Studies on the digestive proteases of the milkfish Chanos chanos. Mar. Biol. 71: 309-315

Beyer, J. M., Lucchetti, G., Gray, G. (1988). Digestive tract evacuation in northern squawfish (Ptychocheilus oregonensis). Can. J. Fish. Aquat. Sci. 45: 548-553

Brett, J. R., Groves, T. D. D. (1979). Physiological energetics. In: Hoar, W. S., Randall. D. J., Brett, J. R. (eds.) Fish physiology, Vol. 8. Bioenergetics and growth. Academic Press, Inc., New York, p. 279-352

Bromley, P. J., Adkins, T C. (1984). The influence of cellulose filler on feeding, growth and utilization of protein and energy in rainbow trout. Salmo gairdnerii Richardson. J. Fish Biol. 24: 235-244

Crisp, D. J. (1984). Energy flow measurements. In: Holme, N. A., McIntyre, A. D. (eds.) Methods for the study of marine benthos. Blackwell Scientific Publications, Oxford, p. $284-372$

Edwards, T W., Horn, M. H. (1982). Assimilation efficiency of a temperate-zone intertidal fish (Cebidichthys violaceus) fed diets of macroalgae. Mar. Biol. 67 247-253

Fange, R., Grove, D. (1979). Digestion. In: Hoar, W. S., Randall, D. J., Brett, J. R. (eds.) Fish physiology, Vol. 8 Bioenergetics and growth. Academic Press, Inc., New York, p. 161-260

Flowerdew, M. D., Grove, D. J. (1979). Some observations of the effects of body weight, temperature, meal size and quality on gastric emptying time in the turbot, Scophthalmus maximus (L.) using radiography. J. Fish Biol. 14: 229-238
Greenway, M. (1976). The grazing of Thalassia testudinum in Kingston Harbor, Jamaica. Aquat. Bot. 2: 117-126

Grove, D. J., Crawford, C. (1980). Correlation between digestion rate and feeding frequency in the stomachless teleost Blennius pholis L. J. Fish Biol. 16: 235-247

Grove, D. J., Loizides, L. G., Nott, J. (1978). Satiation amount, frequency of feeding and gastric emptying rate in Salmo gairdneri. J. Fish Biol. 12: 507-516

Hay, M. E. (1984). Predictable spatial escapes from herbivory how do these affect the evolution of herbivore resistance in tropical marine communities? Oecologia 64: 396-407

Hiatt, R. W., Strasburg, D. W. (1960). Ecological relationships of the fish fauna on coral reefs of the Marshall Islands. Ecol. Monogr. 30: 65-127

Holmgren, S., Grove, D. J., Fletcher, D. J. (1983). Digestion and the control of gastrointestinal motility. In: Rankin, J. C., Pitcher, T. J., Duggan, R. T (eds.) Control processes in fish physiology. John Wiley and Sons, Inc, New York, p. $23-40$

Horn, M. H. (1983). Optimal diets in complex environments feeding strategies of two herbivorous fishes from a temperate rocky intertidal zone. Oecologia 58: 345-350

Horn, M. H. (1989). Biology of marine herbivorous fishes. Oceanogr. mar. Biol. A. Rev. 27: 167-272

Horn, M. H., Murray, S. N., Edwards, T W. (1982). Dietary selectivity in the field and food preferences in the laboratory for two herbivorous fishes (Cebidichthys violaceus and Xiphister mucosus) from a temperate intertidal zone. Mar. Biol. 67: 237-246

Horn, M. H., Neighbors, M. A. (1984). Protein and nitrogen assimilation as a factor in predicting the seasonal macroalgal diet of the monkeyface prickleback. Trans. Am. Fish. Soc. 113: 388-396

Horn, M. H., Neighbors, M. A., Rosenberg, M. J., Murray, S. N. (1985). Assimilation of carbon from dietary and nondietary macroalgae by a temperate-zone intertidal fish Cebidichthys violaceus (Girard) (Teleostei: Stichaeidae). J. exp. mar. Biol. Ecol. 86: 241-253

Hughes, R. N. (1980). Optimal foraging theory in the marine context. Oceanogr. mar. Biol. A. Rev. 18: 423-481

Jobling, M. (1980). Gastric evacuation in plaice, Pleuronectes platessa L.: effects of dietary energy level and food composition. J. Fish Biol. 17: 187-196

Jobling, M. (1981a). Dietary digestibility and the influence of food components on gastric evacuation in plaice, Pleuronectes platessa L. J. Fish Biol. 19: 29-36

Jobling, M. (1981b). Mathematical models of gastric emptying and the estimation of daily rates of food consumption for fish. J. Fish Biol. 19: 245-257

Jobling, M. (1983). A short review and critique of methodology used in fish growth and nutrition studies. J. Fish Biol. 23: $685-703$

Jobling, M. (1986). Mythical models of gastric emptying and implications for food consumption studies. Envir. Biol. Fish. 16: 35-50

Jobling, M. (1987). Influences of food particle size and dietary energy content on patterns of gastric evacuation in fish: test of a physiological model of gastric emptying. J. Fish Biol. 30: 299-314

Jobling, M., Wandsvik, A. (1983). An investigation of factors controlling food intake in Arctic charr, Salvelinus alpinus L. J. Fish Biol. 23: 397-404

Klumpp, D. W. Nichols, P. D. (1983). Nutrition of the southern sea garfish Hyporhamphus melanochir: gut passage rate and daily consumption of two food types and assimilation of seagrass components. Mar. Ecol. Prog. Ser. 12: 207-216 
Knights, B. (1985). Feeding behaviour and fish culture. In: Cowey, C. B., Mackie, A. M., Bell, J. G. (eds.) Nutrition and feeding in fish. Academic Press, Inc., London, p. 223-241

Lawrence, J. M. (1976). Absorption efficiencies of four species of tropical echinoids fed Thalassia testudinum. Thalassia jugosl. 12: 201-205

Littler, M. M., Taylor, P. R., Littler, D. S. (1983). Algal resistance to herbivory on a Caribbean barrier reef. Coral Reefs 2: $111-118$

Lobel, P. S. (1981). Trophic biology of herbivorous reef fishes: alimentary tract $\mathrm{pH}$ and digestive capabilities. J. Fish Biol. 19: $365-397$

Lobel, P. S., Ogden, J. C. (1981). Foraging by the herbivorous parrotfish Sparisoma radians. Mar. Biol. 64: 173-183

Lowe, E. F., Lawrence, J. M. (1976). Absorption efficiencies of Lytechinus variegatus (Lamarck) (Echinodermata: Echinoidea) for selected marine plants. J. exp. mar. Biol. Ecol. 21: $223-234$

Montgomery, W. L. (1980). Comparative feeding ecology of two herbivorous damselfishes (Pomacentridae: Teleostei) from the Gulf of California, Mexico. J. exp. mar. Biol. Ecol. 47: $9-24$

Montgomery, W. L., Gerking, S. D. (1980). Marine macroalgae as foods for fishes: an evaluation of potential food quality. Envir. Biol. Fish. 5: 143-153

Paul, V J. (1987). Feeding deterrent effects of algal natural products. Bull. mar. Sci. 41: 514-522

Paul, V. J., Fenical, W. (1983). Isolation of halimedatrial: chemical defense adaptation in the calcareous reef building alga Halimeda. Science 221: 747-749

Paul, V J., Hay, M. E. (1986). Seaweed susceptibility to herbivory: chemical and morphological correlates. Mar. Ecol. Prog. Ser. 33: 255-264

Persson, L. (1982). Rate of food evacuation in roach (Rutilus rutilus) in relation to temperature, and the application of evacuation rate estimates for studies on the rate of food consumption. Freshwat. Biol. 12: 203-210

This article was presented by Professor B. D. Sidell, Orono, Maine, USA
Pyke, G. H. (1979). Optimal foraging in fish. In: Stroud, R. H., Clepper, H. (eds.) Predator-prey systems in fisheries management. Sport Fishing Institute, Washington, p. 199--202

Pyke, G. H., Pulliam, H. R., Charnov, E. L. (1977). Optimal foraging: a selective review of theory and tests. $Q$. Rev Biol. 52: 137-154

Randall, J. E. (1967). Food habits of reef fishes of the West Indies. Stud. trop. Oceanogr., Miami 5: 665-847

Robblee, M. B., Zieman, J. C. (1984). Diel variation in the fish fauna of a tropical seagrass feeding ground. Bull. mar. Sci 34: 335-345

Rozin, P., Mayer, J. (1961). Regulation of food intake in the goldfish. Am. J. Physiol. 201: 968-974

Sokal, R. R., Rohlf, F. J. (1981). Biometry, 2nd edn. W. H Freeman and Co., San Francisco

Steinberg, P. D. (1984). Algal chemical defense against herbivores: allocation of phenolic compounds in the kelp Alaria marginata. Science 223: 405-407

Steinberg, P. D. (1986). Chemical defenses and the susceptibility of tropical marine brown algae to herbivores. Oecologia 69: 628-630

Targett, N. M., Targett, T. E., Vrolijk, N. H., Ogden, J. C (1986). Effect of macrophyte secondary metabolites on feeding preferences of the herbivorous parrotfish Sparisoma radians. Mar. Biol. 92: 141-148

Thayer, G. W., Bjorndal, K. A., Ogden, J. C., Williams, S. L., Zieman, J. C. (1984). Role of larger herbivores in seagrass communities. Estuaries 7: 351-376

Weatherley, A. H., Gill, H. S. (1987). The biology of fish growth. Academic Press, London

Weinstein, M. P., Heck, K. L. (1979). Ichthyofauna of seagrass meadows along the Caribbean coast of Panama and in the Gulf of Mexico: composition, structure and community ecology. Mar. Biol. 50: 97-107

Wylie, C. R., Paul, V. J. (1988). Feeding preferences of the surgeonfish Zebrasoma flavescens in relation to chemical defenses of tropical algae. Mar Ecol. Prog. Ser. 45: 23-32

Manuscript first received: September 4, 1989

Revised version accepted: May 30, 1990 